\title{
Sweet orange trees grafted on selected rootstocks fertilized with nitrogen, phosphorus and potassium
}

\author{
José Antônio Quaggio(1), Dirceu Mattos Junior(2), Heitor Cantarella ${ }^{(1)}$, Eduardo Sanches Stuchi(3) \\ and Otávio Ricardo Sempionato ${ }^{(3)}$
}

\begin{abstract}
(1)Instituto Agronômico, Centro de P\&D de Solos e Recursos Ambientais, Caixa Postal 28, CEP 13020-970 Campinas, SP. Bolsista do CNPq. E-mail: quaggio@sp.iac.gov.br, cantarella@iac.sp.gov.br (2)Instituto Agronômico, Centro Avançado de Pesquisa Tecnológica do Agronegócio de Citros Sylvio Moreira, Caixa Postal 04, CEP 13490-970 Cordeirópolis, SP. E-mail: ddm@centrodecitricultura.br (3)Estação Experimental de Citricultura de Bebedouro, Rod. Brigadeiro Faria Lima, km 384, CEP 14700-970 Bebedouro, SP. E-mail: stuchi@estacaoexperimental.com.br, otavio@estacaoexperimental.com.br
\end{abstract}

\begin{abstract}
The majority of citrus trees in Brazil are grafted on 'Rangpur lime' (Citrus limonia Osb.) rootstock. Despite its good horticultural performance, search for disease tolerant rootstock varieties to improve yield and longevity of citrus groves has increased. The objective of this work was to evaluate yield efficiency of sweet oranges on different rootstocks fertilized with $\mathrm{N}, \mathrm{P}$, and potassium. Tree growth was affected by rootstock varieties; trees on 'Swingle' citrumelo [Poncirus trifoliata $(\mathrm{L}$.) Raf. $\times$ C. paradisi Macf.] presented the smallest canopy ( $13.3 \mathrm{~m}^{3}$ in the fifth year after tree planting) compared to those on 'Rangpur lime' and 'Cleopatra' mandarin [C. reshni (Hayata) hort. ex Tanaka] grown on the same grove. Although it was observed an overall positive relationship between canopy volume and fruit yield $\left(\mathrm{R}^{2}=0.95^{* *}\right)$, yield efficiency $\left(\mathrm{kg} \mathrm{m}^{-3}\right)$ was affected by rootstocks, which demonstrated 'Rangpur lime' superiority in relation to Cleopatra. Growth of citrus trees younger than 5-yr-old might be improved by $\mathrm{K}$ fertilization rates greater than currently recommended in Brazil, in soils with low $\mathrm{K}$ and subjected to nutrient leaching losses.
\end{abstract}

Index terms: citrus, growth, yields, canopy.

\section{Laranjas-doce sobre diferentes porta-enxertos adubadas com nitrogênio, fósforo e potássio}

\begin{abstract}
Resumo - A maioria dos citros produzidos no Brasil são enxertados em limão 'Cravo’ (Citrus limonia Osb.). Apesar das boas características agronômicas desse porta-enxerto, a procura por variedades tolerantes a doenças, para aumentar a produtividade e longevidade dos pomares cítricos, tem aumentado. O objetivo deste trabalho foi avaliar a eficiência de produção de frutos de laranjas-doce sobre diferentes porta-enxertos e adubadas com N, P e potássio. O crescimento das árvores foi afetado pelas variedades de porta-enxertos estudadas; plantas sobre citrumelo 'Swingle' [Poncirus trifoliata (L.) Raf. $\times$ C. paradisi Macf.] apresentaram o menor volume de copa (13,3 $\mathrm{m}^{3}$ no quinto ano após plantio) quando comparadas àquelas em limão ‘Cravo' e tangerina 'Cleópatra' [C. reshni (Hayata) hort. ex Tanaka] no mesmo pomar. Embora tenha sido observada uma relação positiva entre volume de copa e produção de frutos $\left(\mathrm{R}^{2}=0,95^{* *}\right)$, a eficiência de produção de frutos $\left(\mathrm{kg} \mathrm{m}^{-3}\right)$ foi afetada pelos porta-enxertos, o que demonstrou a superioridade do limão 'Cravo' em relação à 'Cleópatra'. $\mathrm{O}$ crescimento de árvores em formação, com menos que cinco anos de idade, pode apresentar resposta à adubação com K em doses superiores às recomendadas atualmente no Brasil, em solos com baixa reserva de K trocável e condições para perdas deste nutriente por lixiviação.
\end{abstract}

Termos para indexação: citro, crescimento, produtividade, cobertura de copas.

\section{Introduction}

Citrus industry in Brazil represents a major activity, accounting for 13.4 million metric tons of oranges produced in São Paulo State, in 2001/2002 (Abecitrus, 2003). About $75 \%$ of sweet orange trees in that region is grafted on 'Rangpur lime' (Citrus limonia Osb.), a superior cultivar characterized by high vigor and yield, earliness-to-bearing, and drought tolerance (Pompeu Junior, 2001). However, susceptibility of 'Rangpur lime' to citrus blight (Castle et al., 1993) and, more recently to citrus sudden death (MSC - from the Portuguese 
acronym) (Müller et al., 2002) has led to increased use of other rootstocks tolerant to these diseases to improve productivity and longevity of citrus groves.

Rootstocks determine the horticultural performance of citrus trees by affecting growth (Castle et al., 1993), fruit yield and quality (Castle et al., 1988), water relations (Castle \& Krezdorn, 1977; Syvertsen, 1981), and nutrient requirements (Wutscher, 1989).

Size of canopy (tree height, width and volume) is positively related with fruit yield of citrus (Anderson, 1987; Obreza \& Rouse, 1993). This relationship results on availability of leaf area for photosynthesis, flowering and fruit set within trees (Syvertsen \& Lloyd, 1994), even though the number of fruit borne per unit of canopy volume may vary significantly among cultivar combinations. Therefore, this relationship may be used to characterize the yield efficiency of fruit production of trees.

The objective of this work was to evaluate yield efficiency of sweet oranges on different rootstocks fertilized with $\mathrm{N}, \mathrm{P}$, and potassium.

\section{Material and Methods}

This work was conducted in the major citrus producing areas of the State of São Paulo, Brazil, during 1995/1999.

Three citrus groves with 'Pêra' sweet orange [C. sinensis (L.) Osb.] on 'Rangpur lime' (RL) rootstock (C. limonia Osb.), with 'Valencia' sweet orange [C. sinensis (L.) Osb.] on RL and 'Cleopatra' (Cleo) mandarin [C. reshni (Hayata) hort. ex Tanaka] rootstocks, and with 'Natal' sweet orange [C. sinensis (L.) Osb.] on RL, Cleo and 'Swingle' (Sw) citrumelo [Poncirus trifoliata (L.) Raf. $\times$ C. paradisi Macf.] rootstocks were planted in the field in 1995. Pêra grove was located on an Alfisol $\left(117.9 \mathrm{mmol}_{\mathrm{c}} \mathrm{dm}^{-3} \mathrm{CEC}\right.$ at $0-20 \mathrm{~cm}$ depth) on the southeast region of the State, where average temperature is below $20^{\circ} \mathrm{C}$ and there is no water deficit (1,760 mm mean annual rainfall). Other groves were in the north regions; Valencia grove was on an Alfisol (46.5 $\mathrm{mmol}_{\mathrm{c}} \mathrm{dm}^{-3} \mathrm{CEC}$ at $0-20 \mathrm{~cm}$ depth), and Natal grove was on an Oxisol $\left(54.0 \mathrm{mmol}_{\mathrm{c}} \mathrm{dm}^{-3} \mathrm{CEC}\right.$ at $0-20 \mathrm{~cm}$ depth). Average temperature in this region is $23^{\circ} \mathrm{C}$ and mean annual rainfall is about $1,350 \mathrm{~mm}$. Drought periods are common during the winter in this region. Natal grove was located on the uphill of the landscape. Therefore, drought stress was more severe.

Soils at each grove received dolomitic lime application in amounts calculated to raise base saturation $(0-20 \mathrm{~cm}$ depth layer) to approximately 70\% (Quaggio et al., 1992) before tree planting.

Fertilizer treatments were arranged in a fractional factorial design of the $1 / 2\left(4^{3}\right)$ type, with a total of 32 treatments (Andrade \& Noleto, 1986), which consisted of four nutrient rates calculated to be applied during five years: $\mathrm{N}(400,1,000,1,600$ and 2,200 $\mathrm{g}$ tree $\left.^{-1}\right), \mathrm{P}\left(180,440,700\right.$ and $\left.960 \mathrm{~g}^{\text {tree }} \mathrm{e}^{-1}\right)$, and $\mathrm{K}(240$, $660,1,080$ and $1,500 \mathrm{~g}$ tree $\left.^{-1}\right)$. The same arrangement was used in all experimental groves. Annual rates of N, $\mathrm{P}$, and $\mathrm{K}$ were adjusted to account for the tree age every year. Zinc ( $\mathrm{Zn})$, manganese (Mn), and boron (B) were applied by foliar spray according to Quaggio et al. (1997).

Experimental plots consisted of five trees with the middle three used for sampling. Tree growth was estimated by measuring longitudinal and transversal diameters of the canopy, and tree height using a ruler, during the summer in 1997, 1998, and 1999. Canopy volume $\left(\mathrm{m}^{3}\right)$ was calculated using the expression $\mathrm{V}=2 / 3 \pi \mathrm{r}^{2} \mathrm{~h}$, where $\mathrm{V}$ is the canopy volume; $r$ is the canopy radius; and $\mathrm{h}$ is the canopy height. Fruit yield was computed annually by summing up weight of fruits, if more than one harvest per year were necessary.

Data for all groves $(n=192)$, collected in 1998 and 1999 , were pooled in classes of production to verify the relationship of canopy volume and fruit yield. Data collected on Valencia and Natal groves, in 1999, were used to evaluate yield efficiency of citrus rootstocks among treatments. Linear models were estimated by using the GLM procedure of the SAS system (SAS Institute, 1996).

\section{Results and Discussion}

Tree growth increased from the third to the fifth year after planting in the field (Table 1). Overall average canopy volume varied from $3.9 \mathrm{~m}^{3}$ in 1997 to $19.3 \mathrm{~m}^{3}$ in 1999. Canopy volume and diameter of 5-yr-old citrus trees presented high correlation $(\mathrm{r}=0.98 ; \mathrm{P}<0.0001)$. Similarly, the correlation coefficient for canopy volume and plant height was $0.85(\mathrm{P}<0.001)$.

'Rangpur lime' and Cleo produced more vigorous trees than Sw rootstock (Table 1). This effect is characteristic for trifoliate rootstocks and some of its hybrids (Gardner \& Horanic, 1967; Teófilo Sobrinho et al., 1973), and which intensity depends on the level of water deficit. Even though trees on Cleo are more vigorous than those on RL, the opposite was observed on Natal grove (Table 1), located on the uphill of the landscape, where 
Table 1. Growth of 'Valencia' (V) and 'Natal' (N) sweet orange trees on 'Rangpur lime' (RL), 'Cleopatra'(Cleo) mandarin, and 'Swingle' $(\mathrm{Sw})$ citrumelo represented by canopy measurements up to five years after tree planting in different groves ${ }^{(1)}$.

\begin{tabular}{|c|c|c|c|c|c|c|c|c|c|}
\hline \multirow{2}{*}{$\begin{array}{l}\text { Tree/ } \\
\text { rootstock }\end{array}$} & \multicolumn{3}{|c|}{1997} & \multicolumn{3}{|c|}{1998} & \multicolumn{3}{|c|}{1999} \\
\hline & Diameter & Height & $\begin{array}{c}\text { Volume } \\
\left(\mathrm{m}^{3}\right)\end{array}$ & \multicolumn{2}{|c|}{----------(m)--------- } & $\begin{array}{c}\text { Volume } \\
\left(\mathrm{m}^{3}\right)\end{array}$ & \multicolumn{2}{|c|}{------------(m)---------- } & $\begin{array}{c}\text { Volume } \\
\left(\mathrm{m}^{3}\right)\end{array}$ \\
\hline \multicolumn{10}{|c|}{ Valencia grove } \\
\hline V/RL & $1,80(0,13)$ & $1,94(0,09)$ & 3,3 & $2,52(0,19)$ & $2,37(0,14)$ & 7,9 & $3,01(0,21)$ & $2,69(0,19)$ & 12,8 \\
\hline V/Cleo & $1,77(0,14)$ & $1,97(0,08)$ & 3,2 & $2,59(0,19)$ & $2,50(0,15)$ & 8,8 & $3,35(0,21)$ & $3,03(0,20)$ & 17,8 \\
\hline \multicolumn{10}{|c|}{ Natal grove } \\
\hline N/RL & $2,24(0,18)$ & $2,36(0,12)$ & 6,2 & $2,55(0,29)$ & $2,80(0,27)$ & 9,5 & $4,02(0,20)$ & $3,33(0,14)$ & 28,2 \\
\hline N/Cleo & $2,05(0,33)$ & $2,00(0,23)$ & 4,4 & $2,40(0,33)$ & $2,74(0,20)$ & 8,3 & $3,88(0,31)$ & $3,12(0,19)$ & 24,6 \\
\hline $\mathrm{N} / \mathrm{Sw}$ & $1,60(0,28)$ & $1,65(0,20)$ & 2,2 & $2,05(0,32)$ & $2,36(0,33)$ & 5,2 & $3,08(0,27)$ & $2,68(0,20)$ & 13,3 \\
\hline
\end{tabular}

${ }^{(1)}$ Numbers between brackets represent the standard error of the mean $(n=32)$.

more frequent water deficit probably limited greater growth of trees on Cleo - an intermediate drought tolerant rootstock (Davies \& Albrigo, 1994). Trees on Sw are also considered intermediate drought tolerant (Hutchinson, 1974; Stuchi et al., 2000; Figueiredo et al., 2002). The Natal sweet orange, a late season variety has contributed to adverse effects of drought since crop load represents an important sink for water and carbohydrates during fruit maturation (Bustan et al., 1996) throughout the dry season. Thereafter, selection of scion and rootstock combinations considering grove elevation and soil properties is important for appropriate establishment of citrus groves.

Since fertilizer treatments affected growth of same age and scion/rootstock trees on all experimental groves (Mattos Junior, 2000), a significant relationship between canopy volume and fruit yield was verified (Figure 1). Young citrus trees require nutrients for growth and increasingly for fruit yield, which can lead to alternate bearing. This alternate behavior of trees probably determined the large variation in the data. Sixteen-percent fruit yield increase with an increase in canopy volume from 5 to $10 \mathrm{~m}^{3}$ (Figure 1). On the other hand, an increase from 20 to $25 \mathrm{~m}^{3}$, increased fruit yield in $26 \%$. This pattern is possibly explained by the fact that rate of tree growth was smaller for plants with more than $10 \mathrm{~m}^{3}$ in canopy volume, in which fruit load and nutrient sink effects became greater.

Growth and production parameters allowed estimating tree efficiency ( $\mathrm{kg}$ of fruit per $\mathrm{m}^{3}$ of canopy volume) for fruit yield as influenced by rootstocks and fertilizer rates for each rootstock variety. Yield efficiency of trees on RL and Cleo grouped within a similar trend

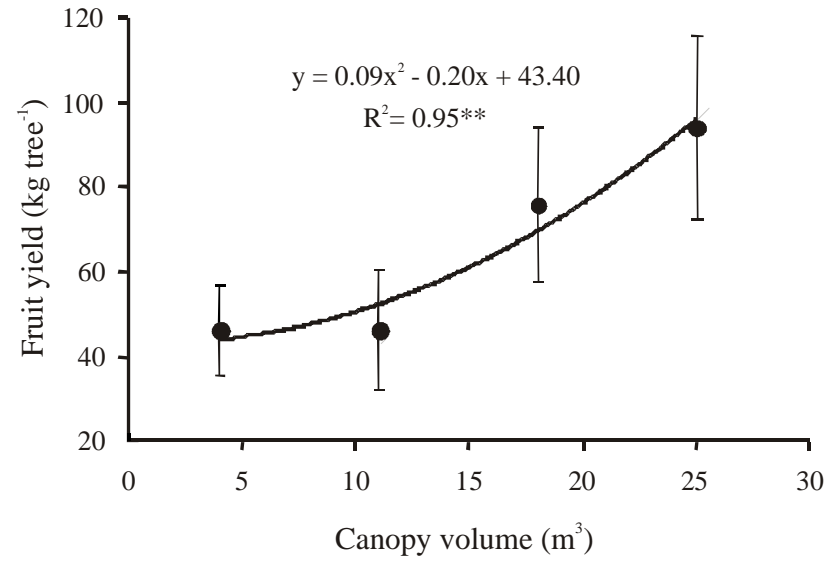

Figure 1. Fruit yield of five-year-old sweet orange trees related to canopy volume. Bars in each point represent the means \pm standard error.

(Figure 2). Trees on RL were more efficient for fruit production compared to those on the former rootstock, even though the proportion of canopy volumes of those was different between experimental groves and over the first years of tree evaluation (Table 1). On the other hand, trees on Sw, which presented smaller canopy, demonstrated that greater fruit yields per tree are only achieved at high tree yield efficiency (Figure 2). This latter observation is important to establish fertilization management of citrus orchards since nutrient requirements of trees on $\mathrm{Sw}$ would be greater for significant crops. Fruit yield of these trees increased with increasing rates of $\mathrm{N}$ and $\mathrm{K}$, with fertilizer rates for maximum yield greater than those observed for trees either on RL or Cleo (Mattos Junior, 2000). Performance 
of those intermediate drought tolerant rootstocks might be improved with adoption of irrigation and correct selection of scion/rootstock combinations and local for grove establishment.

The N, P and K fertilization influenced tree growth, especially the average canopy volume on Pêra grove, in whith significant linear and quadratic responses to $\mathrm{K}$ and $\mathrm{N}$ fertilization were observed (Table 2). The effect of $\mathrm{K}$ rates on canopy volume was positive with an estimated increase on canopy volume from 16.6 to $20.2 \mathrm{~m}^{3}$ and an increase on $\mathrm{K}$ rates from 250 to $1,500 \mathrm{~g}$ tree $^{-1}$ (with $\mathrm{P}=170$ and $\mathrm{N}=2,200 \mathrm{~g}^{2} \mathrm{tree}^{-1}$ ) (Figure 3). Current fertilizer recommendations for young citrus trees ( $<5$-yr-old) in Brazil suggest application of greater amounts of N and P than K (Quaggio et al., 1997). Potassium requirements of trees are only expected to be greater at high fruit yield since it is required in small quantities for vegetative growth, whereas $\mathrm{K}$ removal by fruit harvest is large (Mattos Junior et al., 2003). Data of the present work suggest that where low soil exchangeable $\mathrm{K}$ and high rainfall occur, $\mathrm{K}$ becomes a limiting nutrient for tree growth and therefore $\mathrm{K}$ recommendation for young citrus trees need to be better considered.

The lack of significant response of tree growth to $\mathrm{P}$ fertilization on Pêra grove can be explained by the fact that initial $\mathrm{P}$ level at soil surface was relatively high $\left(22 \mathrm{mg} \mathrm{dm}^{-3}\right.$ ) and increased to above $60 \mathrm{mg} \mathrm{dm}^{-3}$ in the fifth year of $P$ fertilizer application. There was no positive response of fruit yield for bearing trees when soil P levels are higher than $20 \mathrm{mg} \mathrm{dm}^{-3}$ (Quaggio et al., 1998).

Tree growth response was less clear on Valencia grove since only average canopy diameter was significantly affected by treatments either for trees on
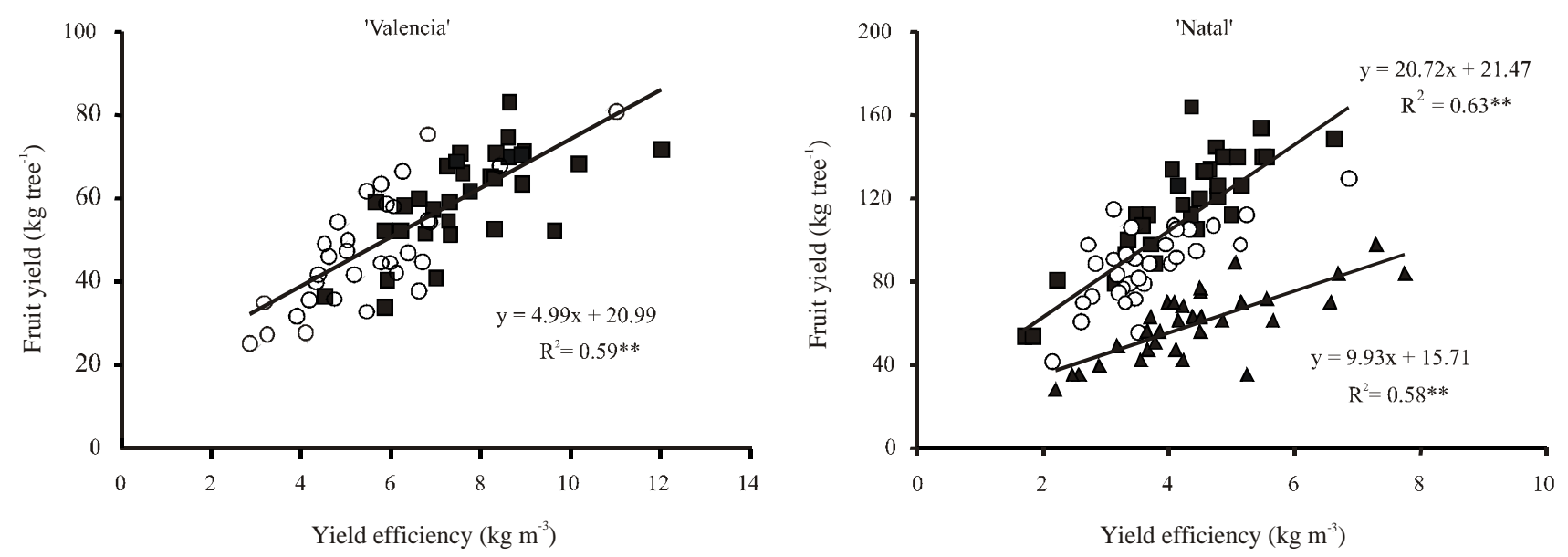

Figure 2. Yield efficiency of 'Valencia' and 'Natal' sweet oranges trees on 'Rangpur lime' ( $\square)$, 'Cleopatra' mandarin (O), and 'Swingle' citrumelo $(\mathbf{\Delta})$ rootstocks.

Table 2. Regression models for average tree canopy volume in the forth and fifth years after tree planting as affected by NPK fertilization.

\begin{tabular}{|c|c|c|c|c|c|c|c|c|c|c|c|}
\hline \multirow[t]{2}{*}{$\operatorname{Tree}^{(1)}$} & \multicolumn{10}{|c|}{ Model coefficient ${ }^{(2)}$} & \multirow[t]{2}{*}{$\mathrm{R}^{2}$} \\
\hline & $\mathrm{b}_{0}$ & $\mathrm{~N}$ & $\mathrm{~N}^{2}$ & $\mathrm{P}$ & $\mathrm{P}^{2}$ & $\mathrm{~K}$ & $\mathrm{~K}^{2}$ & NP & NK & $\mathrm{PK}$ & \\
\hline $\mathrm{P} / \mathrm{RL}$ & 17.4 & $-5.8 \mathrm{E}-03$ & $2.2 \mathrm{E}-06 * *$ & $5.7 \mathrm{E}-03$ & $-2.9 \mathrm{E}-06$ & $3.8 \mathrm{E}-03 *$ & $-1.2 \mathrm{E}-06$ & $-1.5 \mathrm{E}-06$ & $6.7 \mathrm{E}-07$ & $-1.9 \mathrm{E}-06$ & 0.54 \\
\hline V/RL & 8.0 & $1.5 \mathrm{E}-03$ & $-2.6 \mathrm{E}-07$ & $-8.1 \mathrm{E}-04$ & 3.9E-06 & $4.0 \mathrm{E}-03$ & $-1.6 \mathrm{E}-06$ & $-2.3 E-06$ & $-1.3 \mathrm{E}-08$ & $-5.5 E-07$ & 0.31 \\
\hline V/Cleo & 8.4 & $4.3 \mathrm{E}-03$ & $-9.8 \mathrm{E}-07$ & $1.7 \mathrm{E}-03$ & $8.8 \mathrm{E}-07$ & $1.1 \mathrm{E}-03$ & $3.6 \mathrm{E}-07$ & $-8.0 \mathrm{E}-07$ & $-7.1 \mathrm{E}-07$ & 3.6E-07 & 0.33 \\
\hline N/RL & 24.8 & $-3.3 \mathrm{E}-04 *$ & $-1.2 \mathrm{E}-06$ & $-1.8 \mathrm{E}-02$ & $8.1 \mathrm{E}-06$ & $1.2 \mathrm{E}-03$ & $-7.8 \mathrm{E}-07$ & $4.9 \mathrm{E}-06^{* *}$ & $-6.0 \mathrm{E}-07$ & $2.5 \mathrm{E}-06$ & 0.40 \\
\hline N/Cleo & 16.1 & $-5.1 \mathrm{E}-03$ & $1.3 \mathrm{E}-06$ & $1.7 \mathrm{E}-02$ & $-1.3 \mathrm{E}-05$ & $-1.8 \mathrm{E}-03$ & $3.8 \mathrm{E}-06$ & $1.9 \mathrm{E}-06$ & $-2.5 \mathrm{E}-07$ & $-6.8 \mathrm{E}-06$ & 0.36 \\
\hline $\mathrm{N} / \mathrm{Sw}$ & 11.3 & $8.2 \mathrm{E}-05^{*}$ & $-1.1 \mathrm{E}-06$ & $1.6 \mathrm{E}-03$ & $-8.6 \mathrm{E}-06$ & $-7.9 \mathrm{E}-04$ & $1.0 \mathrm{E}-08$ & $3.2 \mathrm{E}-06^{*}$ & $-1.6 \mathrm{E}-07$ & $3.0 \mathrm{E}-06$ & 0.46 \\
\hline
\end{tabular}

(1)P: 'Pêra'; V: 'Valencia'; N: 'Natal' sweet oranges; RL: 'Rangpur lime'; Cleo: 'Cleopatra' mandarin; Sw: 'Swingle' citrumelo rootstocks. ${ }^{(2)} \mathrm{v}=\mathrm{b}_{0}+\mathrm{b}_{1} \mathrm{~N}+\mathrm{b}_{2} \mathrm{~N}^{2}+\mathrm{b}_{3} \mathrm{P}+\mathrm{b}_{4} \mathrm{P}^{2}+\mathrm{b}_{5} \mathrm{~K}+\mathrm{b}_{6} \mathrm{~K}^{2}+\mathrm{b}_{7} \mathrm{NP}+\mathrm{b}_{8} \mathrm{NK}+\mathrm{b}_{9} \mathrm{PK}$, where $\mathrm{v}$ is the average canopy volume $\left(\mathrm{m}^{3}\right)$ and $\mathrm{N}, \mathrm{P}$, and $\mathrm{K}$ are total rates of nutrient $\left(\mathrm{g}\right.$ tree $\left.^{-1}\right)$ supplied during 5 years after tree plant. * and **Significant at 0.05 and 0.01 probability level, respectively. 


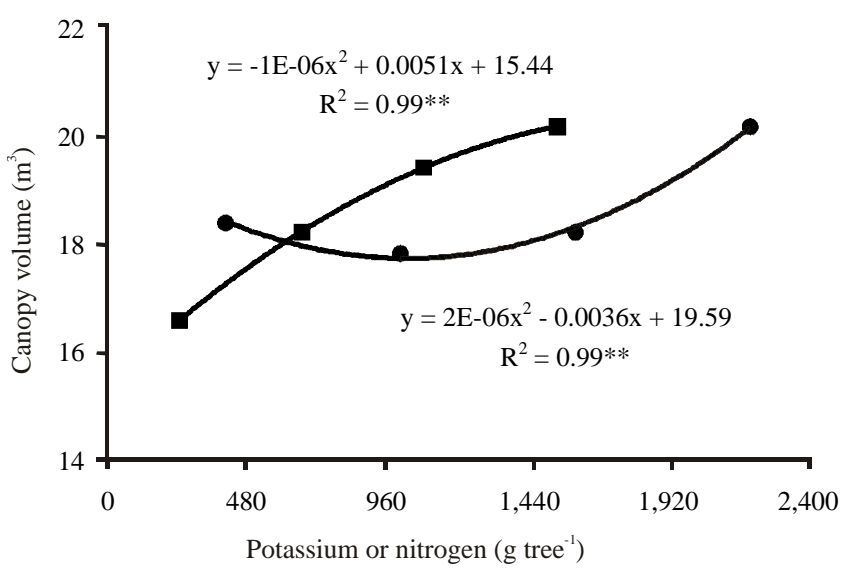

Figure 3. Growth of four- to five-year-old 'Pêra' sweet orange trees on 'Rangpur lime' rootstock as affected by $\mathrm{N}(\boldsymbol{\bullet})$ and $\mathrm{K}$ (ם) fertilization, at $\mathrm{P}$ rate of $170 \mathrm{~g}$ tree ${ }^{-1}$.

RL or Cleo rootstocks (Mattos Junior, 2000). Other factors, such as soil acidity, probably limited tree growth in comparison with other groves. On the other hand, average canopy volume of trees either on RL or Sw showed significant effects of $\mathrm{N}$ and $\mathrm{P}$ fertilization on Natal grove (Table 2). The response models found for either rootstock estimated positive responses to $\mathrm{N}$ fertilization only at $\mathrm{P}$ rates above $700 \mathrm{~g} \mathrm{tree}^{-1}$ (with $\mathrm{K}=240 \mathrm{~g} \mathrm{tree}^{-1}$ ).

\section{Conclusions}

1. 'Swingle' citrumelo induces smaller canopy than 'Rangpur lime' and 'Cleopatra' mandarin rootstocks.

2. There is a positive relationship between canopy volume and fruit yield, even though yield efficiency may vary for trees on 'Rangpur lime' and 'Cleopatra' mandarin.

3. Greater fruit yield of trees on $\mathrm{Sw}$ is achieved at higher tree efficiency compared with those on 'Rangpur lime' and 'Cleopatra' mandarin.

4. Potassium fertilization affects vegetative growth of young trees (<5-yr-old) where low levels of soil exchangeable $\mathrm{K}$ and the likelihood of leaching losses are limiting to citrus production.

\section{Acknowledgements}

To Fundação de Amparo à Pesquisa do Estado de São Paulo, for the financial support (Proc. 95/6611-1 and 96/0829-8); to the Estação Experimental de Citricultura de Bebedouro, Cambuhy Agrícola, and Guacho Agropecuária, for technical assistance.

\section{References}

ABECITRUS. Orange production: historical series. Available at: <http:// www.abecitrus.com.br/cropus.html>. Accessed on: April $12,2003$.

ANDERSON, C.A. Fruit yields, tree size, and mineral nutrition relationships in 'Valencia' orange trees as affected by liming. Journal of Plant Nutrition, v.10, p.1907-1917, 1987.

ANDRADE, D.F.; NOLETO, A.Q. Exemplos de fatoriais fracionados $(1 / 2) 4^{3}$ e $(1 / 4) 4^{4}$ para ajuste de modelos polinomiais quadráticos. Pesquisa Agropecuária Brasileira, v.21, p.677-680, 1986.

BUSTAN, A.; GOLDSCHMIDT, E.E.; ERNER, Y. Carbohydrate supply and demand during fruit development in relation to productivity of grapefruit and 'Murcott' mandarin. Acta Horticulturae, v.416, p.81-88, 1996.

CASTLE, W.S.; KREZDORN, A.H. Soil water use and apparent root efficiencies of citrus trees on four rootstocks. Journal of the American Society for Horticultural Science, v.102, p.403-406, 1977.

CASTLE, W.S.; TUCKER, D.P.H.; KREZDORN, A.H.; YOUTSEY, C.O. Rootstocks for Florida citrus: rootstock selection, the first step to success. $2^{\text {nd }}$ ed. Gainesville: University of Florida, 1993. $92 \mathrm{p}$.

CASTLE, W.S.; WUTSCHER, H.K.; YONTSEY, C.O.; PELOSI, R.R. Citrumelos as rootstocks for Florida citrus. Proceedings of the Florida State Horticultural Society, v.101, p.28-33, 1988.

DAVIES, F.S.; ALBRIGO, L.G. Citrus. Wallingford: CAB International, 1994. 254p.

FIGUEIREDO, J.O.; STUCHI, E.S.; DONADIO, L.C.; TEÓFILO SOBRINHO, J.; LARANJEIRA, F.F.; PIO, R.M.; SEMPIONATO, O.R. Porta-enxertos para a lima-ácida 'Tahiti' na região de Bebedouro, SP. Revista Brasileira de Fruticultura, v.24, p.155-159, 2002.

GARDNER, F.E.; HORANIC, G.E. Poncirus trifoliata and some of its hybrids as rootstocks for Valencia sweet orange. Proceedings of the Florida State Horticultural Society, v.53, p.85-87, 1967.

HUTCHINSON, D.J. Swingle citrumelo: a promising rootstock hybrid. Proceedings of the Florida State Horticultural Society, v.87, p.89-91, 1974.

MATTOS JUNIOR, D. Citrus response functions to $\mathbf{N}, \mathbf{P}$, and $\mathbf{K}$ fertilization and $\mathbf{N}$ uptake dynamics. 2000. 133p. Thesis (Ph.D.) - University of Florida, Gainesville.

MATTOS JUNIOR, D.; QUAGGIO, J.A.; CANTARELLA, H.; ALVA, A.K. Nutrient content of biomass components of Hamlin sweet orange trees. Scientia Agricola, v.60, p.155-160, 2003.

MÜLLER, G.W.; NEGRI, J.D.; AGUILAR-VILDOSO, C.I.; MATTOS JUNIOR, D.; POMPEU JUNIOR, J.; TEÓFILO SOBRINHO, J.; MACHADO, M.A.; GIROTTO, L.F. Morte súbita dos citros: uma nova doença na citricultura brasileira. Laranja, v.23, p.371-386, 2002 .

OBREZA, T.A.; ROUSE, R.E. Fertilizer effects on early growth and yield of 'Hamlin' orange trees. HortScience, v.28, p.111-114, 1993. 
POMPEU JUNIOR, J. Rootstocks and scions in the citriculture of the São Paulo State. In: WORLD CONGRESS THE INTERNATIONAL SOCIETY OF CITRUS NURSERYMEN, 6., 2001, Ribeirão Preto. Proceeding. Ribeirão Preto: International Society of Citrus Nurserymen, 2001. p.75-82.

QUAGGIO, J.A.; CANTARELLA, H.; RAIJ, B. van. Phosphorus and potassium soil test and nitrogen leaf analysis as basis for citrus fertilization. Nutrient Cycling in Agroecosystems, v.52, p.67-74, 1998.

QUAGGIO, J.A.; RAIJ, B. van; PIZA JUNIOR, C.T. de. Frutíferas. In: RAIJ, B. van; CANTARELLA, H.; QUAGGIO, J.A.; FURLANI, A.M.C. Recomendações de adubação e calagem para o Estado de São Paulo. 2.ed. Campinas: Instituto Agronômico, 1997. 285p. (Boletim Técnico, 100).

QUAGGIO, J.A.; TEÓFILO SOBRINHO, J.; DECHEN, A.R. Response to liming of 'Valencia' orange tree on Rangpur lime: effects of soil acidity and plant growth and yield. Proceedings of the International Society of Citriculture, v.2, p.623-632, 1992.
SAS INSTITUTE (Cary, United States). The SAS system: release 6.12. Cary, 1996. 1 CD-ROM.

STUCHI, E.S.; DONADIO, L.C.; SEMPIONATO, O.R. Tolerância à seca da laranjeira 'Folha Murcha' em 10 porta-enxertos. Revista Brasileira de Fruticultura, v.22, p.454-457, 2000.

SYVERTSEN, J.P. Hydraulic conductivity of four commercial citrus rootstocks Journal of the American Society for Horticultural Science, v.106, p.378-381, 1981.

SYVERTSEN, J.P.; LLOYD, J. Citrus. In: SCHAFFER, B.; ANDERSEN, P. (Ed.). Handbook of environmental physiology of fruit crops. Boca Raton: CRC Press, 1994. v.2, p.65-99.

TEÓFILO SOBRINHO, J.; SIMÃO, S.; BARBIN, D.; POMPEU JUNIOR, J. Produtividade por metro cúbico e vigor na laranjeira Valência sobre diferentes porta-enxertos. In: CONGRESSO BRASILEIRO DE FRUTICULTURA, 2., 1972, Viçosa, MG. Anais. Viçosa: Sociedade Brasileira de Fruticultura, 1973. v.1, p.331-341.

WUTSCHER, H.K. Alteration of fruit tree nutrition through rootstocks. HortScience, v.24, p.578-584, 1989. 